\title{
Pseudorhapydionininae of the Iberian Ranges (Cenomanian, Iberian Peninsula)
}

\section{Lorenzo CONSORTI ${ }^{1 *}$, Amelia CALONGE ${ }^{2}$ \& Esmeralda CAUS ${ }^{1}$}

${ }^{1}$ Departament de Geologia (Paleontologia), Universitat Autònoma de Barcelona, 08193 Bellaterra, Spain; lorenzo.consorti@ e-campus.uab.cat; esmeralda.caus@uab.cat

${ }^{2}$ Facultad de Educación, Universidad de Alcalá, c/ Madrid 1, 19001 Guadalajara, Spain; a.calonge@uah.es

* Corresponding author

Consorti, L., Calonge, A. \& Caus, E. 2016. Pseudorhapydionininae of the Iberian Ranges (Cenomanian, Iberian Peninsula). [Subfamilia Pseudorhapydionininae de la Cordillera Ibérica (Cenomaniense, Península Ibérica)]. Spanish Journal of Palaeontology, 31 (2), 271-282.

\begin{abstract}
Pseudorhapydionina laurinensis, P. dubia, P. anglonensis and Pseudorhipidionina casertana (Subfamily Pseudorhapydionininae) from the Iberian Range are restudied. The age of the deposits containing these species is late Cenomanian. However, a small Pseudorhapydionina (named in this work as $P$. aff. laurinensis) occurs in the lower Cenomanian deposits suggesting that the origin of the group is in the earliest Cenomanian.
\end{abstract}

Keywords: Pseudorhapydionininae, porcelaneous foraminifera, Cenomanian, Iberian Ranges, Spain.

\section{RESUMEN}

En este trabajo se han restudiado los géneros Pseudorhapydionina laurinensis, P. dubia, P. anglonensis y Pseudorhipidionina casertana (Subfamilia Pseudorhapydionininae) de la Cordillera Ibérica. La edad asignada a los depósitos que contienen estos taxones es Cenomaniense superior. No obstante, especímenes de pequeño tamaño, atribuidos en este trabajo a $P$. aff. laurinensis, han sido también encontrados en dépositos atribuidos al Cenomaniense inferior, lo que sugiere un origen del grupo en la base del Cenomaniense.

Palabras clave: Pseudorhapydionininae, foraminíferos porcelanáceos, Cenomaniense, Cordillera Ibérica, España. 


\section{INTRODUCTION}

The Iberian Ranges consist of a NW-SE intra-plate fold belt extending about $400 \mathrm{~km}$ in length and more than $200 \mathrm{~km}$ in width at the east of the Iberian Peninsula, and surrounded by the Ebro, Duero and Madrid basins and the Valencia Trough (Capote et al., 2002). The Iberian Ranges were formed as the result of the Alpine Orogeny, and within them, five structural units are identified: the Demanda-Cameros (NW), Aragonian Branch (central NE), Maestrazgo (SE), Castilian Branch (central SW) and Sierra de Altomira (SW) (Fig. 1a). The Castilian Branch and Maestrazgo units have been the only ones considered in this work. The Catalanids are included in the latter unit.

During Cenomanian times, the area currently occupied by the Iberian Ranges was a SE-NW elongated intracontinental basin (Iberian Basin) developed between the Iberian and Ebro massifs, acting as a seaway between the Tethyan Ocean in the south-east and the Atlantic Ocean towards the north (Caus et al., 2009 and the papers cited therein). In this basin, the development of shallow-water carbonate platforms with a tropical to subtropical climate and an oligotrophic to mesotrophic environmental regime favored the settlement of an abundant fauna of porcelaneous foraminifera with a high to moderate k-strategy, such as the
Alveolinoideans and the Soritoideans. The former group was widely studied in the 1930s by Reichel (1936-37), and updated later by Calonge et al. (2002) and Vicedo et al. (2011), but no new detailed studies have been made after the work of Calonge $(1989,1996)$ for the Soritaceans.

Thus, the aim of this work is to restudy the representatives of the Pseudorhapydionininae subfamily from the Iberian Ranges (E of Spain) in order to enhance their biostratigraphic and palaeogeographic distribution in this area of the western Tethys, in the context of the Cenomanian Soritoidean revision. The study has been based mainly on four sections from the Serranía de Cuenca (Castilian Branch, Cuenca province), although complementary samples have been also taken in the Maestrazgo (Puerto de Villarroya and Puerto del Remolcador sections, Teruel and Castellon provinces), and from the Catalanids outcrops (Prat de Compte, Llaveria and Tarragona, Tarragona province) (Fig. 1b). Moreover, material collected by Calonge (1989) and deposited in the University of Alcalá de Henares was also re-studied. The new material treated in this work has been deposited at the Department of Geology of the Universitat Autònoma de Barcelona. The figured specimens are deposited in the collection of Palaeontology under the acronym PUAB 82473-82479.

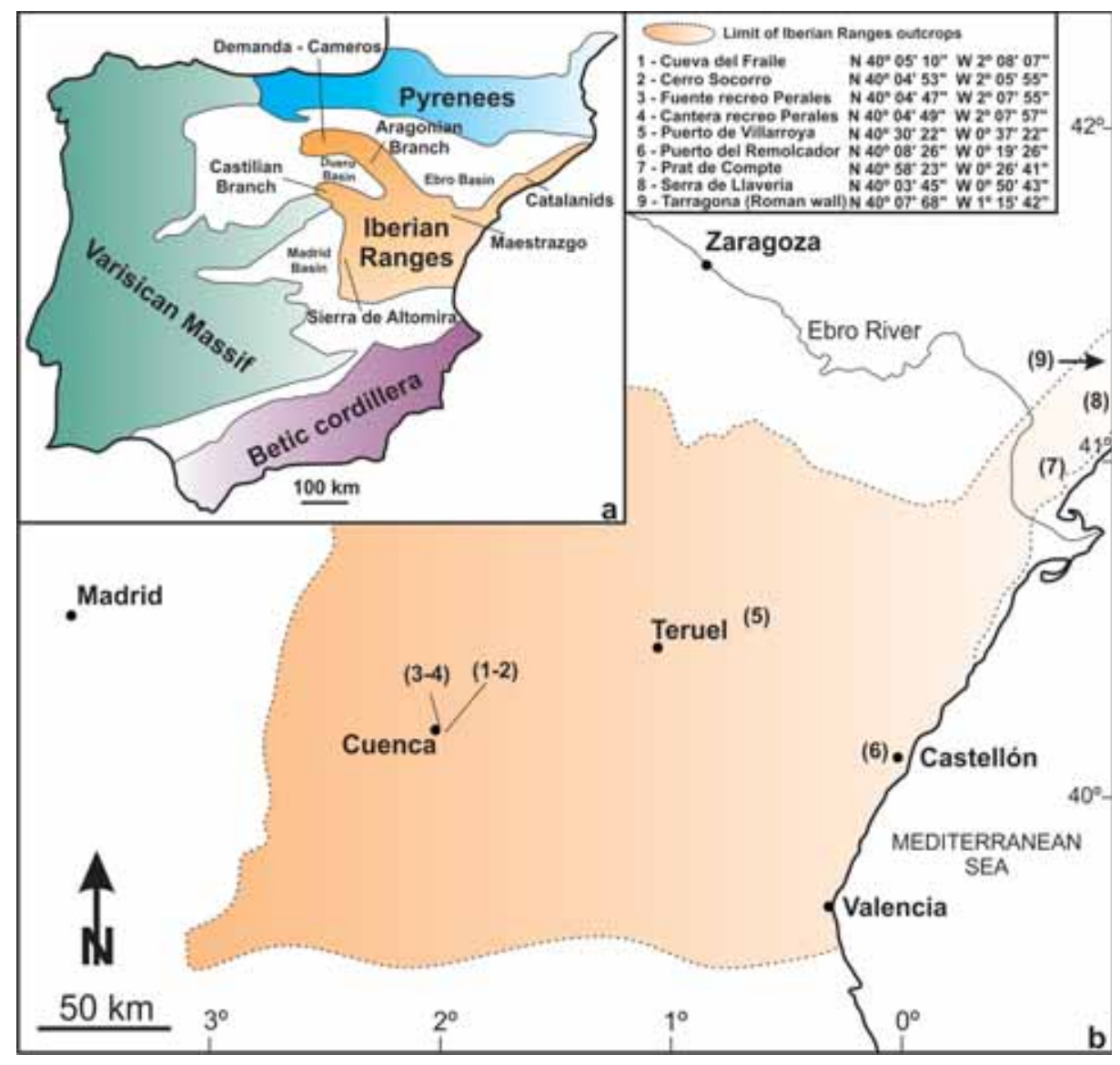

Figure 1. a) Location of the Iberian Ranges in the Iberian Peninsula. b) Position of the studied sections and outcrops. 1-4 Castilian Branch (Serranía de Cuenca): 1. Cueva del Fraile; 2. Cerro Socorro; 3. Fuente de Recreo Perales; 4. Cantera de Recreo Perales; 5-6 Maestrazgo: 5. Puerto de Villarroya (A-226 road); 6. Puerto del Remolcador (CV190 road); 7-9 Catalanids: 7. Prat de Compte; 8. Serra de Llaveria; 9. Tarragona (Roman wall). See Calonge (1989) for further information. 


\section{CENOMANIAN STRATIGRAPHY}

In the Iberian Ranges, the Cenomanian sequence is divided generally into five lithostratigraphic units (Vilas et al., 1982). From bottom to top, they are (Fig. 2):

1. Chera Formation. This basal unit is constituted by green marls interbedded with partially dolomitized grey limestones. The unit contains a rich fauna of oysters and larger foraminifera; among this last group Cuneolina pavonia d'Orbigny, Orbitolina (Conicorbitolina) cf. cuvillieri (Moullade), O. (C.) corbarica Schroeder, Peneroplis parvus De Castro, Ovalveolina maccagnoe De Castro, Sellialveolina quintanensis Vicedo, Calonge $\&$ Caus (note that this species is generally named Sellialveolina gr. vialli in previous works), and rare small Praealveolina iberica Reichel. The age of this unit is earliest Cenomanian (Caus et al., 2009). The Chera Formation, latest Albian in age (Caus et al., 2009), overlays the Aras de Alpuente Formation.

This unit yields Pseudorhapydionina aff. laurinensis.

2. Alatoz Formation. This consists of laminated limestone and dolostone, characterized mainly by the occurrence of Praealveolina iberica associated to
O. (Orbitolina) concava (Lamark), O. (O.) duranddelgai Schroeder and Charentia cuvillieri Neumann, among others. The age is early Cenomanian (Caus et al., 2009).

3. Villa de Ves Formation. This unit comprises thinbedded to massive limestones intercalated with marly limestones passing upwards to dolostone. The larger foraminifera are represented by Orbitolina (C.) conica (d'Archiac), Charentia cuvillieri, Praealveolina debilis Reichel and Sellialveolina gutzwilleri Vicedo, Calonge $\&$ Caus. In addition, a rich association of nezzazatids (Nezzazata simplex Omara, Merlingina cretacea Hamaoui \& Saint Marc, Biplanata peneropliformis Hamaoui \& Saint Marc, Biconcava bentori Hamaoui \& Saint Marc and Coxites zubairensis Smout) characterizes this unit. A middle Cenomanian age is given to this unit (Calonge et al., 2002; Caus et al., 2009).

4. Casa Medina Formation. Nodular limestone and dolomites with a rich fauna of porcelaneous foraminifera that include alveolinids (Praealveolina tenuis Reichel, Praealveolina simplex Reichel, Ovalveolina ovum (d'Orbigny) and $O$. cf. crassa De Castro) and pseudorhapydionines (Pseudorhapydionina dubia De Castro, P. anglonensis Cherchi \& Schroeder,

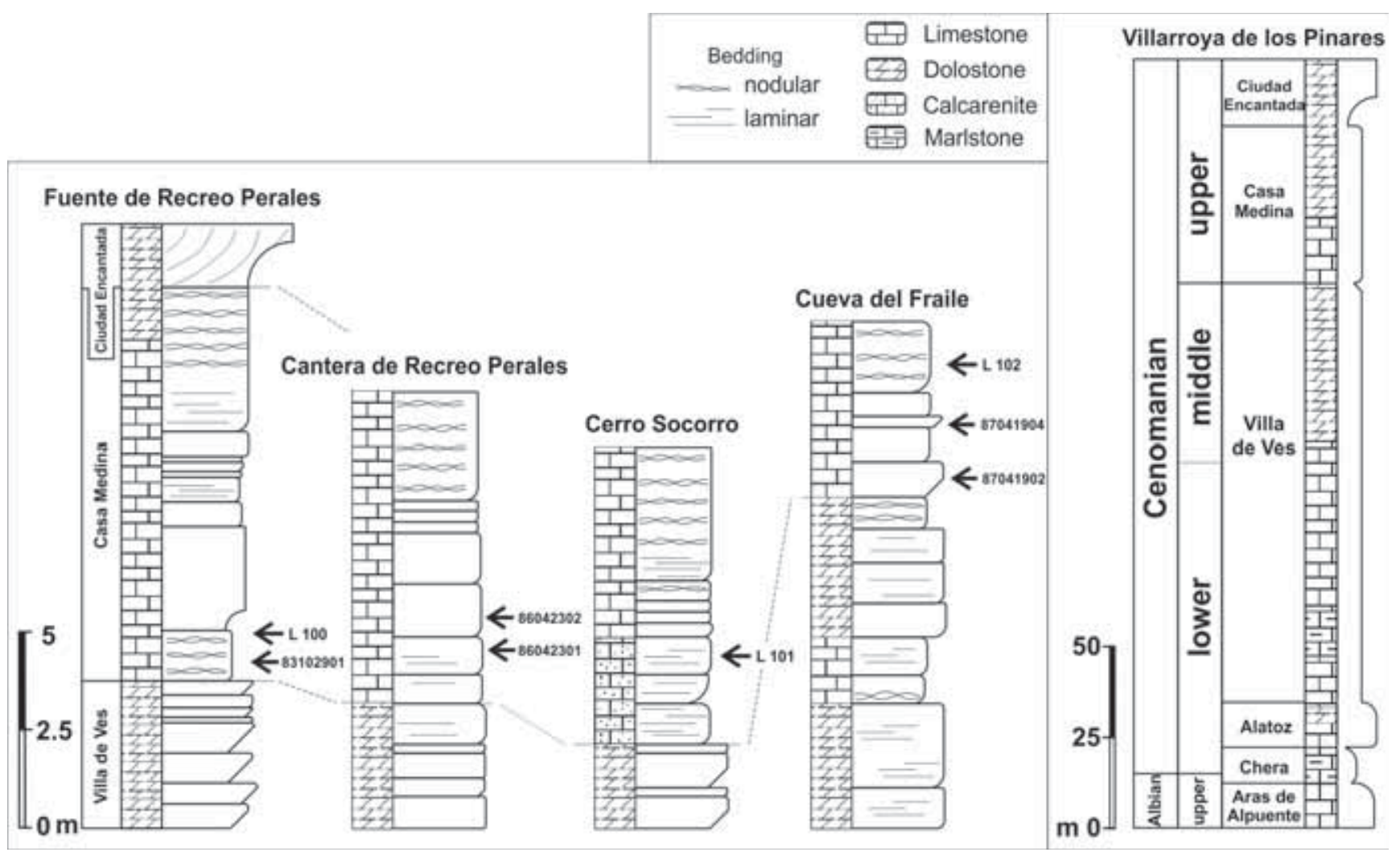

Figure 2. Schematic correlation of the Serranía de Cuenca sections (Castilian Branch) with the stratigraphic position of the samples containing Pseudorhapydionines. Note that the reference section is from Villarroya de los Pinares section (Maestrazgo) (redrawn from Caus et al., 2009). See coordinates in Fig. 1B. Samples repository: L100 = PUAB 82475; L101 = PUAB 82476; L102 = PUAB 82478. Remaining samples have been taken from Calonge (1989). 
P. laurinensis De Castro and Pseudorhipidionina casertana De Castro). No orbitolinids or rhapydioninids are present in this unit, which is dated as late Cenomanian.

5. Ciudad Encantada Formation. The unit is constituted mainly by dolomites, and the larger foraminifera occur only sporadically when the dolomitization is less intense.

In the Catalanids, the deposits of Cenomanian age are represented only by a few meters of limestone and dolomites attributed to the Serra de Llaveria Formation (Robles, 1982), which are contemporaneous with the Casa Medina and Ciudad Encantada Formations. In this area the Cenomanian deposits lie on the terrigenous Utrillas Formation. The limestones of the Serra de Llaveria Formation contain Pseudorhapydionina dubia, P. anglonensis, P. laurinensis and Pseudorhipidionina casertana.

From a depositional point of view, the Cenomanian deposits of the Iberian Basin belong to two consecutive cycles, separated by a major unconformity occurring at the middle Cenomanian. At that time an important sealevel drop caused a regional episode of subaerial exposure across most Iberian shallow marine areas (Giménez, 1987; Martín-Chivelet \& Giménez, 1993). The deposits of the lower cycle are represented by Chera, Alatoz, and Villa de Ves, while those of the upper cycle are constituted by the Casa Medina and Ciudad Encantada formations or their contemporaneously equivalent deposits in the Catalanids.

\section{SYSTEMATICS}

Phylum FORAMINIFERA d'Orbigny, 1826 Pawlowski et al., 2013

Class TUBOTHALAMEA Pawlowski et al., 2013 Order MILIOLIDA (Delage \& Hérouard, 1896) Pawlowski et al., 2013

Remarks. In this paper the classification used for high-level categories, such as phylum, class, and order categories, is from Pawlowski et al. (2013).

Superfamily Soritoidea Ehrenberg, 1839

Remarks. Following Consorti et al. (2016) the Superfamily Soritoidea should be restricted to porcelaneous foraminifera with planispiral early arrangement of the chambers in A and B generations that may later become uncoiled, flabelliform, or annular, in the adult stage.

Family Praerhapydioninidae Hamaoui \& Fourcade, 1973
Remarks. See Consorti et al. $(2015,2016)$ for discussion about the Praerhapydioninidae family.

Subfamily Pseudorhapydionininae Consorti et al., 2016

Type Genus Pseudorhapydionina De Castro, 1972

Genus Pseudorhapydionina De Castro, 1972

Type species Rhapydionina laurinensis De Castro, 1965

Description. Globular to subcylindrical porcelaneous foraminifer with planispiral-involute chamber arrangement in the early stage of growth, becoming generally uncoiled in the adult stage. The aperture is cribrate. The marginal chamber lumen is partially subdivided by radial septula. For further details see De Castro in Schroeder \& Neumann (1985).

\section{Pseudorhapydionina dubia (De Castro, 1965)} (Figs 3a-3g)

Description. Porcelaneous shell with subglobular-tocylindrical morphology. The chambers in the early stage of growth are arranged in one and a half to two whorls. The specimens of the Iberian Ranges show four chambers in the first whorl and six or seven in the second one. The uncoiled adult stage consists generally of five cylindrical chambers. The globular early stage reaches a maximum diameter of $0.35 \mathrm{~mm}$ with an average of $0.29 \mathrm{~mm}$. The seriate adult stage has an average length of $0.6 \mathrm{~mm}$ and the height of the chambers is approximately $0.06 \mathrm{~mm}$. The scarce centered sections show a proloculus of about $40 \mu \mathrm{m}$ in diameter. The apertural face is convex and the aperture cribate. The intercameral foramina are regularly disposed, forming a circular pattern with three concentric stipple rings in the septa. The chamber lumen is partially divided by radial septula, which number approximately 5-6 per quadrant in the seriate adult stage of growth. Septula are short and their thickness is less than $10 \mu \mathrm{m}$.

Remarks. The concentric ring pattern of the foramina observed in the P. dubia from the Iberian Ranges can be also observed in De Castro (1985; Pl. 41, Figs 2-6). The circular outline of foraminal disposition is referred always to the seriate chambers. Their presence in the spirally arranged chambers has not been observed.

Stratigraphical and geographical distribution. Pseudorhapydionina dubia is a common species in the late Cenomanian of the Iberian Ranges. It frequently occurs in the Serranía de Cuenca (Casa Medina Formation) and in Prat de Compte (Serra de Llaveria Formation).

Pseudorhapydionina anglonensis Cherchi \& Schroeder, 1985

(Fig. 3h) 

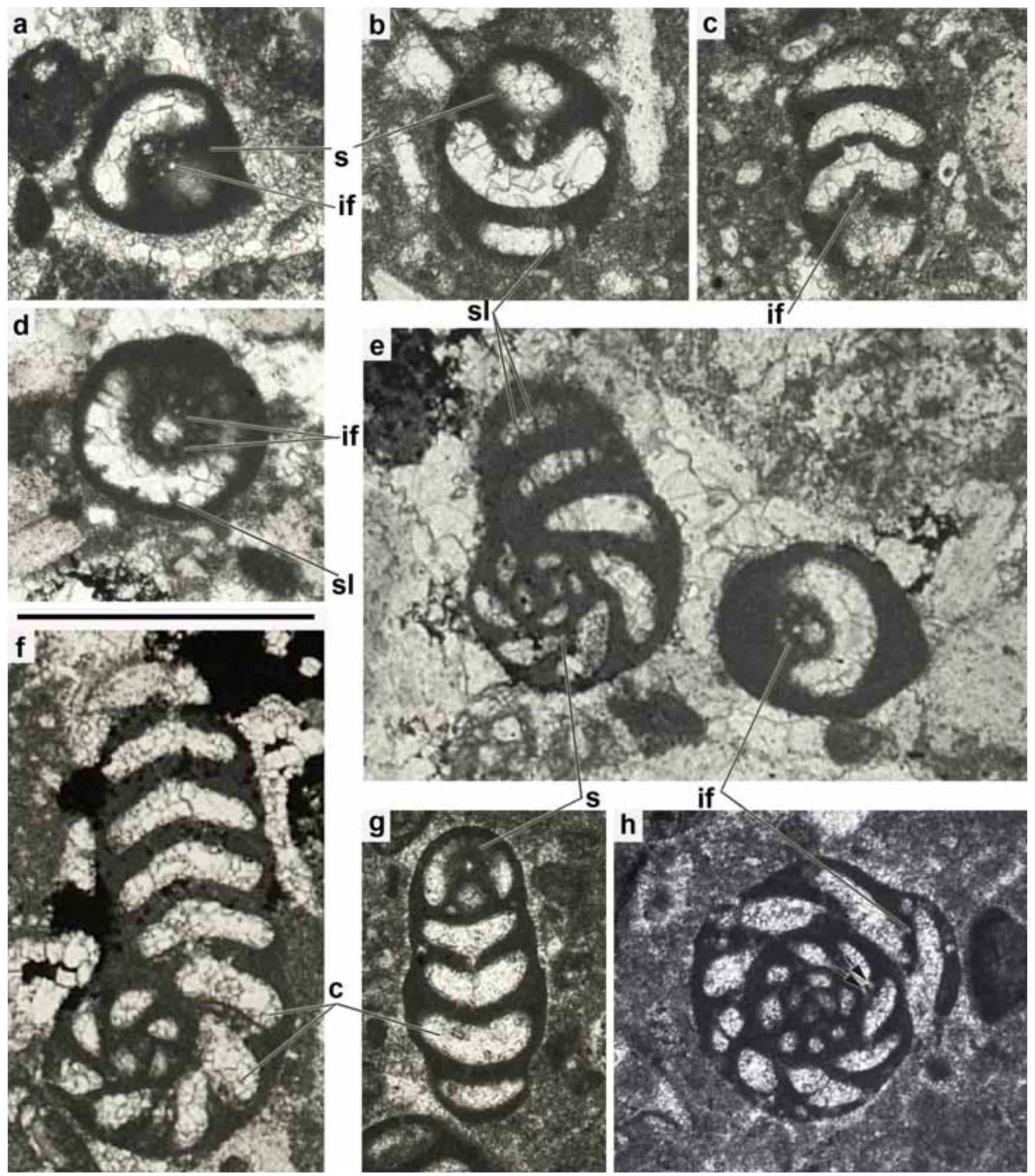

Figure 3. Scale bar $0.5 \mathrm{~mm}$ for all specimens. (a-f) Pseudorhapydionina dubia from Prat de Compte (PUAB 82473 LP01 and LP02). a) Transverse slightly oblique section. Note intercameral foramina piercing septum. b) Oblique section. Intercameral foramina and septula are visible. c) Badly preserved longitudinal section. d) Tranverse section. The cut show septulae and intercameral foramina piercing septum. e) Close to the equatorial (left side) and tranverse slightly oblique (right side) sections. f) Close to the equatorial section. Four seriate chambers are visible. (g) P. dubia from Serra de Llaveria (sample 80092401 of Calonge, 1989). Longitudinal section. In the upper part, the convexity of the septum simulates the presence of a simple unique aperture. This also happens in a, b, d. (h) Equatorial section of Pseudorhapydionina anglonensis from Serra de Llaveria (sample 80092401 of Calonge, 1989). The section shows few septula (lower part) and intercameral foramina in interiomarginal position (lasts chambers). Apertures in interimarginal position are also visible in earlier growth stage (arrows). c: chamber; if: intercameral foramina; s: septum; sl: septulum. 
Description. Porcelaneous globular shell lacking the seriate stage of growth typical of the other species of the genus Pseudorhapydionina. The chambers are arranged in 2.5 planispiral whorls. The first whorl consists of seven chambers, the second of eight, while the last incomplete whorl is composed of five chambers. The shells have an average diameter of $0.48 \mathrm{~mm}$, while their proloculi are around $30 \mu \mathrm{m}$. The septa are convex and cribbed by foramina located in the interiomarginal position. Pseudorhapydionina anglonensis has few and short radial septula subdividing the chamber lumen.

Remarks. Cherchi \& Schroeder (1985) state that cribrate aperture is present just in the last chambers, while a simple aperture is present in the early ontogenetic stage of growth. However, in the Iberian material at our disposition, the cribrate aperture is also observed in the early steps of growth (see the arrows in Fig. 3h).

Stratigraphical and geographical distribution. Pseudorhapydionina anglonensis has been only found in the Serra de Llaveria Formation (Catalanids).

\section{Pseudorhapydionina laurinensis (De Castro, 1965)} (Figs 4a-4b)

Description. Porcelaneous, subgloblar-to-cylindrical shell. The subglobular early stage, with a size of about $0.33 \mathrm{~mm}$ of diameter, consists of two whorls of planispiral chambers. The first whorl hosts six chambers, while the second one has ten. The diameter of the proloculus is approximately $30 \mu \mathrm{m}$. The height of the cylindrical chambers is approximately $0.05 \mathrm{~mm}$. The chamber lumen is partially divided by long radial septula, which number approximately 5-6 per quadrant in the seriate stage of growth. Septula thickness is around $15 \mu \mathrm{m}$. For further information see De Castro (1985) and Consorti et al. (2016).

Remarks. In the deposits of the Chera Formation (early Cenomanian) of the Puerto del Remolcador section (see Calonge, 1989 for details), some specimens of a small Pseudorhapydionina ( $P$. aff. laurinensis in this work) have been observed (Fig. 4a). These specimens differ from $P$. laurinensis type by the smaller size of their adult shells and proloculi. However, the material at our disposal is not enough to prove if it is a new species characterizing the older deposits than those containing $P$. laurinensis. It is worth noting that De Castro (1985) also mentioned " $P$. laurinensis" in association with S. vialli in the deposits of early Cenomanian of southern Italy, although the author does not figure it.

Stratigraphical and geographical distribution. Pseudorhapydionina laurinensis is rare in the studied samples. It has only been found in the deposits of the
Serra de Llaveria Formation, although Calonge (1996) mentioned this species in the deposits of the Castilian branch (Puerto de Villarroya and Morrón de Pinarueco sections). The late Cenomanian age of the specimens of the Iberian Ranges coincides with the age of the P. laurinensis type (De Castro, 1985).

Genus Pseudorhipidionina De Castro, 1972

Type species Rhipidionina casertana De Castro, 1965

Description. Flat, porcelaneous foraminifer with planispiral-involute chamber arrangement in the early stage of growth, becoming uncoiled and flabelliform in the adult stage. The elongate apertural face is pierced by multiple non-aligned openings (cribrate aperture). The marginal chamber lumen is partially subdivided by radial septula. See De Castro in Schroeder and Neumann (1985) for further details.

\section{Pseudorhipidionina casertana De Castro, 1972 (Figs 4d-4e, 4h, 5a-5j)}

Description. Porcelaneous flabelliform shell with an acute periphery. The early planispiral-involute stage of growth consists of elongated chambers arranged in one and a half to two whorls, reaching a diameter of 0.55 $\mathrm{mm}$, approximately. The seriate stage is composed, at least, of 10 wide and short chambers averaging $0.04 \mathrm{~mm}$ in height. The septa are markedly convex and cribbed by numerous intercameral foramina. The external part of the chamber lumen is partially divided by radial septula. The septula, which has a thickness of around 15-18 $\mu \mathrm{m}$, may bifurcate at their inner end. They occupy one-third of the chamber lumen.

Remarks. The presence of bifurcate septula has never been highlighted in this taxon, although the character seems to be present with high frequency, especially in the seriate stage of growth. Bifurcate septula are visible in our material and in the specimens figured by De Castro (1985; Pl. 45, Fig. 6).

De Castro (2006) transferred a foraminifer to the genus Pseudorhipidionina that was previously described by Crescenti (1964) as Praerhapydionina murgiana. However, the small biometrical differences between $P$. murgiana (Crescenti) and P. casertana De Castro (see Table 2 in De Castro, 2006) may suggest they are synonyms, although further studies should be done.

Stratigraphical and geographical distribution. This species is widely distributed in the upper Cenomanian samples of the Casa Medina and Serra de Llaveria Formations. It has also been found in the Cenomanian clasts reworked in the Tertiary foreland conglomerates of the Ebro Basin. 

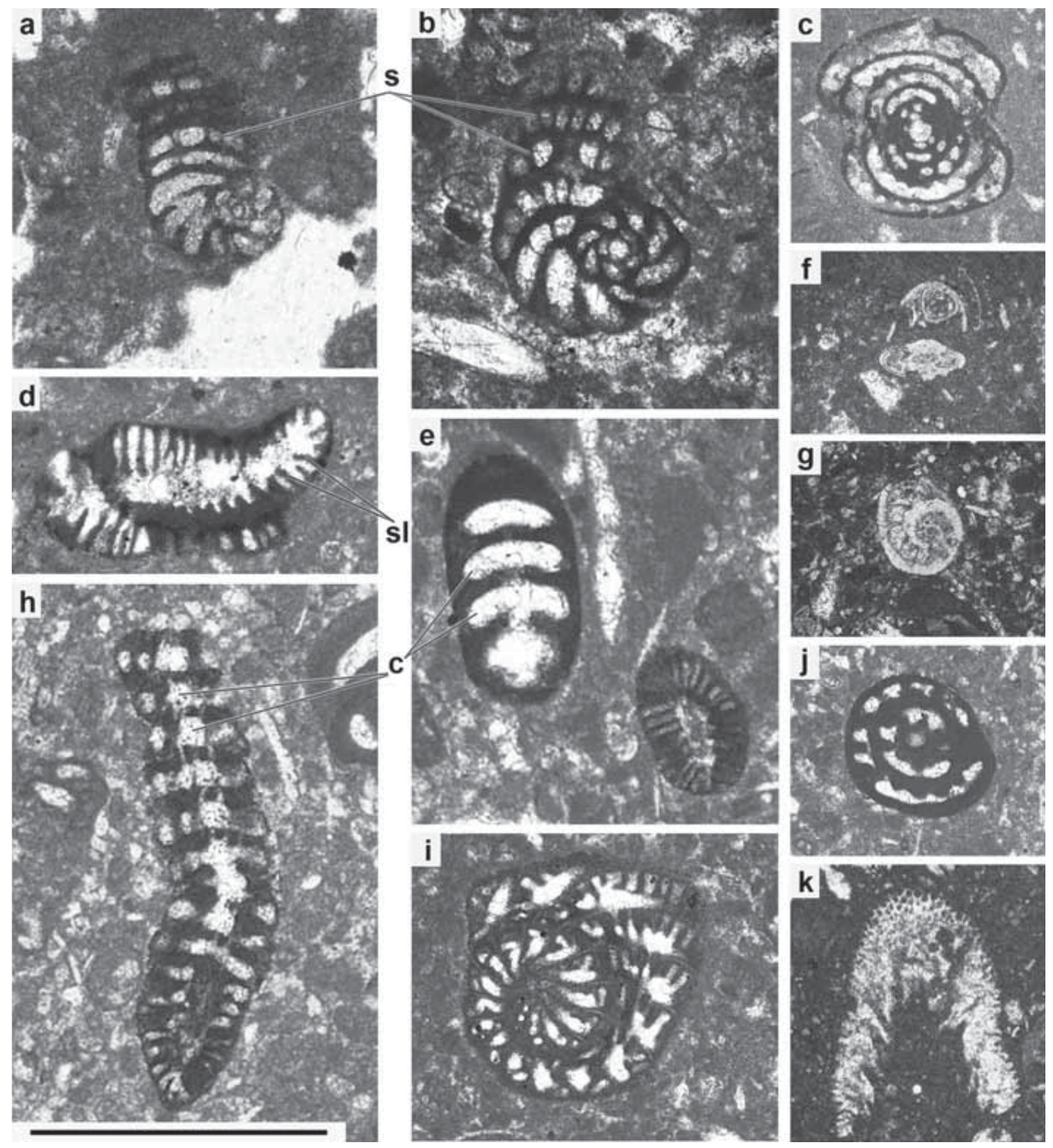

Figure 4. Scale bar $0.5 \mathrm{~mm}$ for figures a, b, d, e, h. a) Equatorial section of $P$. aff. laurinensis from Chera Formation in Puerto del Remolcador (PUAB 82479 LP01). b) Equatorial section of P. laurinensis from Serra de Llaveria (sample 80092401 of Calonge, 1989). d) Pseudorhipidionina casertana from Serra de Llaveria (sample 80092401 of Calonge, 1989). Obliquetransverse section of seriate chambers. Note bifurcation at the inner end of a septulum. e) Oblique-longitudinal section of a $P$. dubia (left side) and P. casertana in transverse section (right side). Specimens from Fuente de Recreo Perale (PUAB 82475 LP02). h) $P$. casertana in longitudinal section. Cut also shows the preceding whorl in the spiral stage of growth (lower side of the picture). Specimens from Fuente de Recreo Perale (PUAB 82475 LP02). Scale bar $1 \mathrm{~mm}$ for associate fauna in figures c, f, g, i, j, k. (c, f, i, j, k) Specimens from Cerro Socorro (PUAB 82476 LP02-03); (g) from Fuente de Recreo Perales (PUAB 82475 LP03). c) Cisalveolina cf. lehneri. f, g) Axial and equatorial section respectively of Rotorbinella mesogeensis. (i) Coxites zubairensis in transverse section j) Ovalveolina sp. k) Green algae. c: chamber; s: septum; sl: septula. 

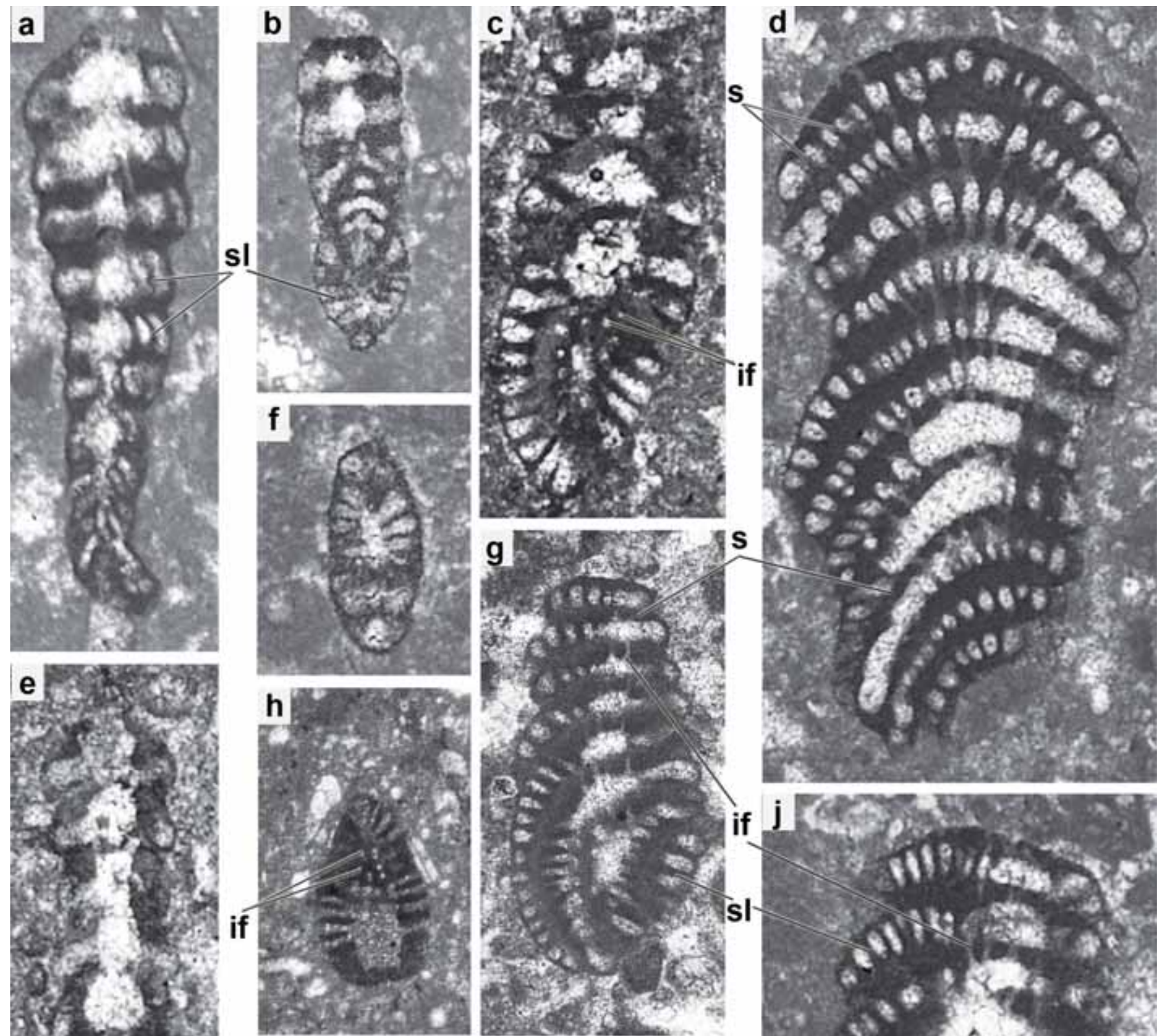

if

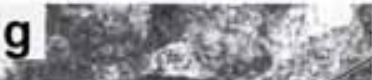

S
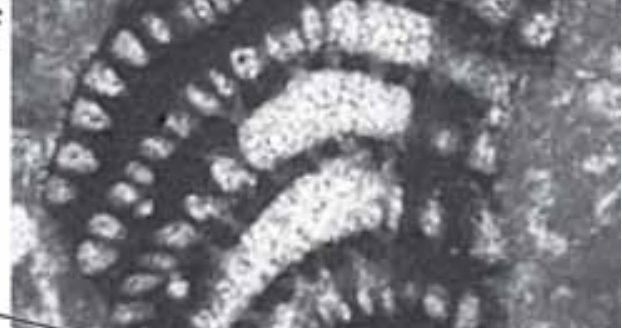

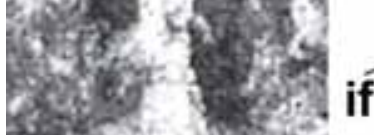

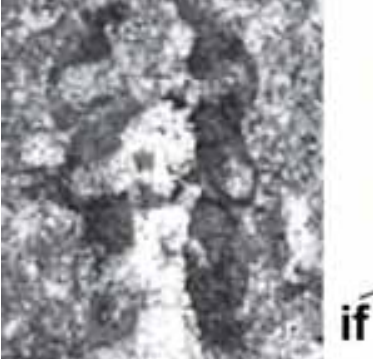

Q9.
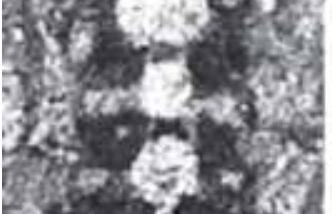

Sents

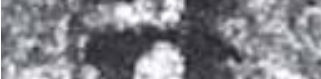

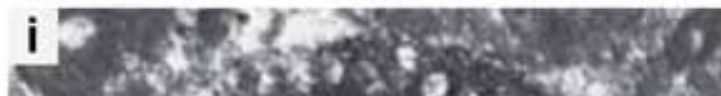

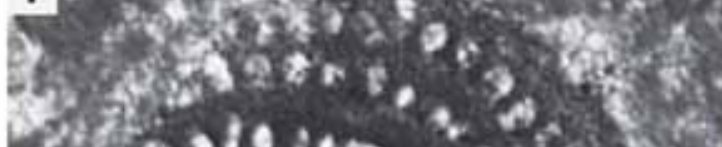

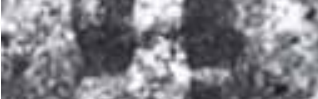

2034052

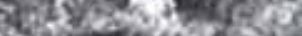
(3)

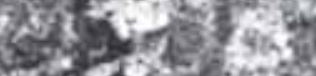

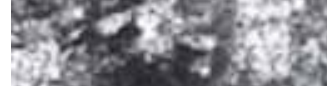

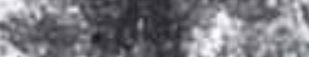
$2805010.000 \%$

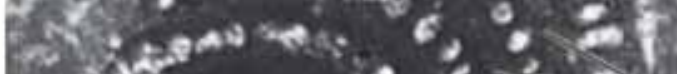

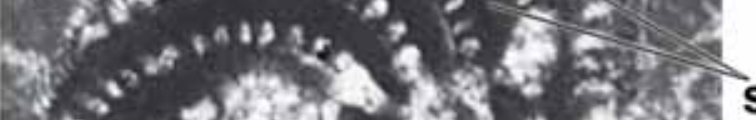

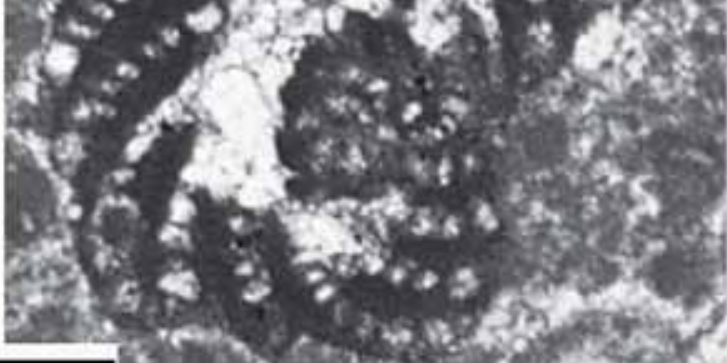

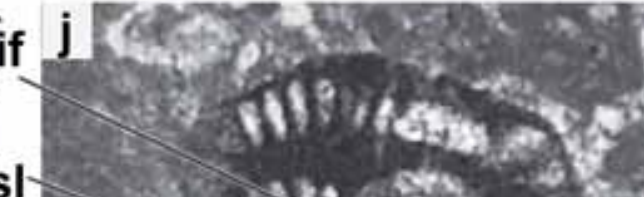

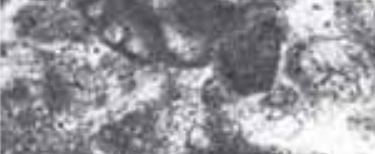

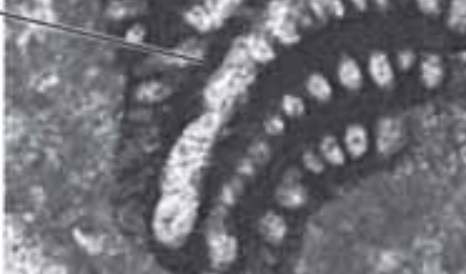

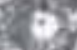
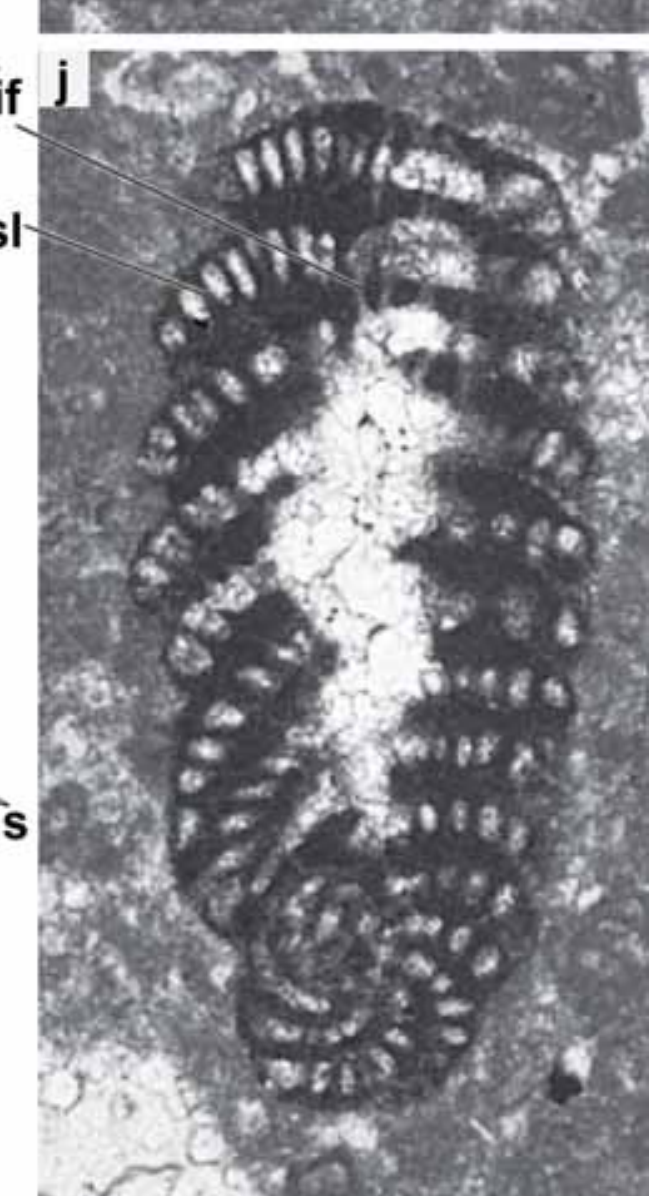
Figure 5. Pseudorhipidionina casertana. Scale bar 0.5. (a, c, e) Specimens from Cueva del Fraile section; (b, f) from a clast in Tertiary deposits near Prat de Compte; (d, g, i, j) from Fuente de Recreo Perales section; (h) from Serra de Llaveria section. a) Longitudinal section showing septula (PUAB 82473 LP01). b) Near to the axial section, septula are shown in the lower part of the specimen (PUAB 82474 LP01). c) Longitudinal section, septum cut tangentially shows intercameral foramina (sample 87041904). d) Oblique-tangential section of the seriate stage of growth. Septula are absent where cut intercept inner cameral spaces (PUAB 82475 LP01). e) Longitudinal section of a badly preserved specimen (sample 87041904). f) Transverse slightly oblique section of a small chamber (PUAB 82474 LP01). g) Oblique section of several seriate chambers (sample 83102901). h) Transverse section showing intercameral foramina (sample 80092401-2 of Calonge, 1989). i) Close to the equatorial section of a badly preserved specimen (PUAB 82475 LP02). j) Oblique-longitudinal section, seriate chambers are partially dissolved in their central part (PUAB 82475 LP02). if: intercameral foramina; s: septum; sl: septulum.

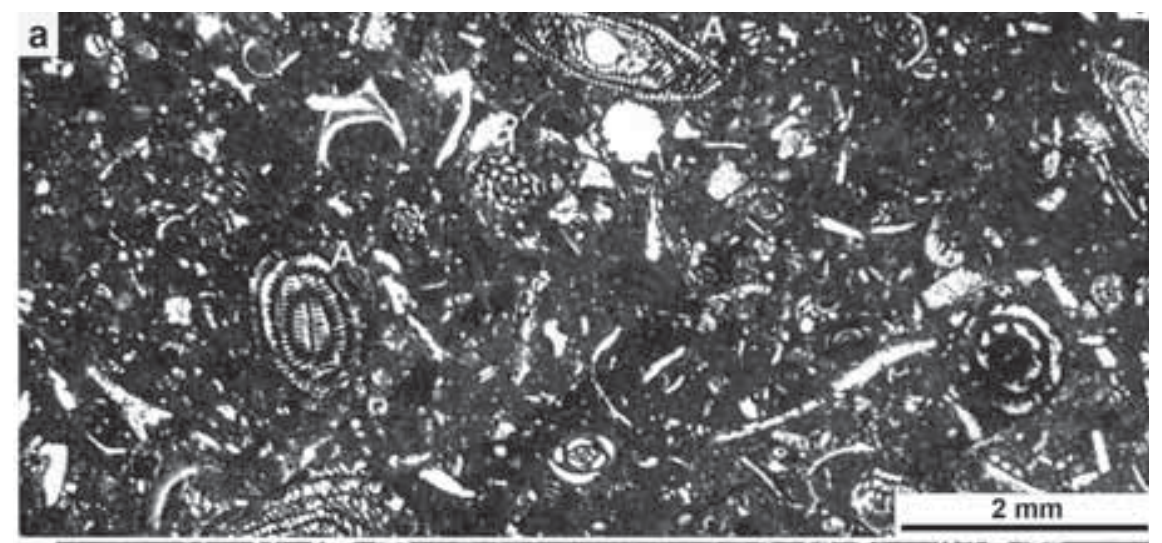

Figure 6. a) Facies from Cerro Socorro section, Serranía de Cuenca (sample L101). Wackestonepackstone with alveolinids (A). The microfacies also contains Cuneolina sp., Pseudorhipidionina casertana, Rotorbinella mesogeensis, Coxites zubairensis, nezzazatids, miliolids, green algae and rudist fragments. b) Facies from the Cueva del Fraile section, Serranía de Cuenca (sample L102). Wackestone-packestone with Pseudorhipidionina casertana (P), green algae $(\mathrm{G})$ and alveolinids (A). The microfacies contains also few miliolids, nezzazatids, green algae and rudist fragments. c) Facies from Parco-Peragine (near Bari, SE of Italy), sampled in the same locality of De Castro (2006). Wackestone-packstone with Psuedorhipidionina 'murgiana' (P), Crysalidina gradata (C), miliolids and echinoderm fragments. In the same sample Coxites zubairensis, Cisalveolina fraasi, Pseudolituonella reicheli, Dicyclina schlumbergeri, nezzazzatids and trocholinids are also present. 


\section{PAlaEOENVIRONMENT, AgE AND PALAEOBIOGEOGRAPHY}

The facies bearing Pseudorhapydionines from Iberian Ranges are interpreted as shallow-water carbonate platform deposits, ranging from lagoonal to littoral facies. They consist of packstone-wackestones with abundant porcelaneous foraminifera, mainly Praealveolina, small rotaliids, some agglutinating forms, green algae, and rudist fragments (Figs 6a-6b). The Iberian facies differ from most of the contemporaneous facies from southern Italy (type localities of P. dubia, P. laurinensis and $P$. casertana) because the latter contain miliolids and Cisalveolina (Fig. 6c).

In the Iberian Ranges, Pseudorhapydionina laurinensis, P. dubia, P. anglonensis and Pseudorhipidionina casertana occur only in the deposits of the upper sedimentary cycle (Casa Medina and Serra de Llaveria Formations), attributed to the late Cenomanian (Praealveolina brevis and $P$. tenuis biozones, Calonge et al., 2002). They are mainly associated with alveolinids (Praealveolina brevis and $P$. tenuis) and nezzazatids. Rotorbinella mesogeensis is also present. This age is concordant with that attributed to this association in other areas of the Mediterranean Sea and Middle East (De Castro in Schroeder \& Neumann, 1985 and the papers cited therein; Whittaker et al., 1998; Parente et al., 2008; Chiocchini et al., 2012; Consorti et al., 2015 among others). Outside the Iberian Ranges, the abovementioned taxa are in the same strata as Cisalveolina fraasi, a marker for the late Cenomanian (De Castro, 1983; Frijia et al., 2015).

However, the presence of small forms (P. aff. laurinensis in this paper) associated with Sellialveolina quintanensis in the deposits of the Chera Formation suggests that the first representatives of the Pseudorhapydionininae appear in the Iberian Ranges at least at the base of the Cenomanian.

From a palaeogeographical point of view, Pseudorhapydionina dubia, P. laurinensis and Pseudorhipidionina casertana showed a broader distribution along the Cenomanian Tethyan shallowwater deposits, from the eastern shores of the Iberian Peninsula and Sardinia at the northwest to the Zagros Mountains in Iran, and probably Oman at the southeast (Fig. 7). Pseudorhapydionina anglonensis has been only mentioned in the Iberian Peninsula (this work), Sardinia (Cherchi \& Schroeder, 1985), and central Italy (Chiocchini et al., 2012). However, the lack of references from this species in the Middle East may be due to a mistake in its identification due to the difficulties to distinguish the juvenile tests of $P$. anglonesis and $P$. dubia.

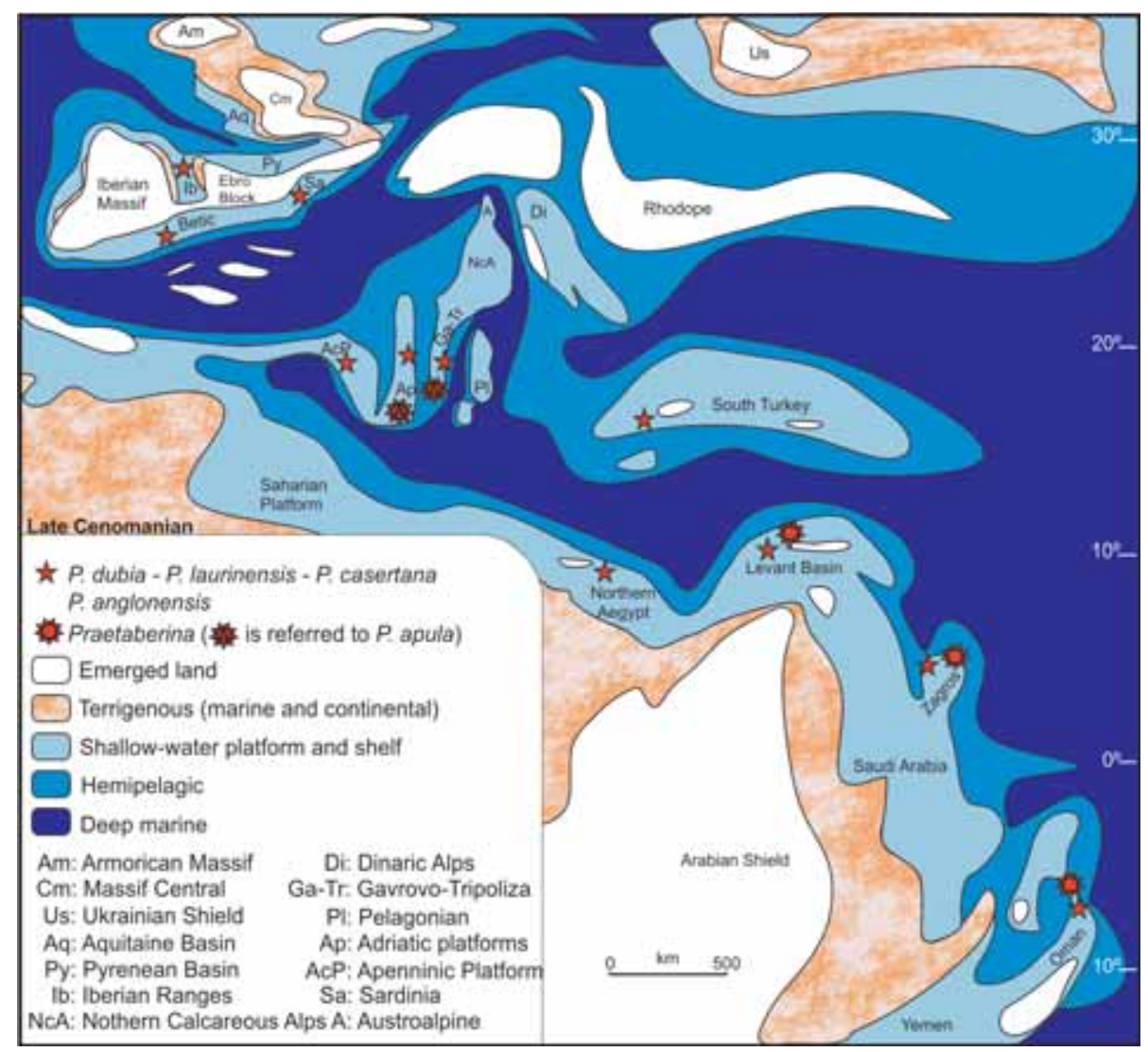

Figure 7. Palaeogeographic reconstruction of central and eastern Tethys during late Cenomanian. Redrawn and simplified after Dercourt et al. (2000), Caus et al. (2009), and Zarcone et al. (2010). References for each locality: Iberian Ranges (Calonge, 1989, 1996 and this work); Greece (Fleury, 1980); Sardinia (Cherchi \& Schroeder, 1985); Adriatic platforms (De Castro, 2006; Velić, 2007; Spalluto, 2012); Apenninic Platform (De Castro, 1965; Chiocchini et al., 2012); north of Egypt (Bauer et al., 2002); south of Turkey (Bignot \& Poisson, 1974); Lebanon, Levant Basin (Saint-Marc, 1974); Iran and Oman (Smith et al., 1990; Afghah \& Fadei, 2014; Consorti et al., 2015). 


\section{CONCLUSIONS}

In the Iberian Ranges, the subfamily Pseudorhapydionininae is represented by Pseudorhapydionina laurinensis, P. dubia, $P$. anglonensis and Pseudorhipidionina casertana. These species characterize the shallow-water carbonate deposits of the Cenomanian upper sedimentary cycle (Casa Medina and Ciudad Encantada Formations), late Cenomanian in age. However, in the deposits of the lowermost lower sedimentary cycle (Chera Formation), a small Pseudorhapydionina, named here as $P$. aff. laurinensis, occurs. Its age is early Cenomanian, which places the origin of the group, at least, in the earliest Cenomanian.

\section{ACKNOWLEDGMENTS}

The program "Ayuda a la Investigación de la Sociedad Española de Paleontología" is gratefully acknowledged. We thank the project of the Spanish Ministry of Economía y Competitividad (project CGL2012-33160) for providing supplementary financial support. We thank M. Reolid for reviewing the manuscript and J. Aguirre for his careful editorial handling.

\section{REFERENCES}

Afghah, M. \& Fadei, H.R. 2014. Biostratigraphy of Cenomanian successions in Zagros area (south west of Iran). Geosciences Journal, 19, 257-271; doi: 10.1007/ s12303-014-0045-3.

Bauer, J., Kuss, J. \& Steuber, T. 2002. Platform environments, microfacies and systems tracts of the upper Cenomanian - lower Santonian of Sinai, Egypt. Facies, 47, 1-26; doi: 10.1007/BF02667703.

Bignot, G. \& Poisson, A. 1974. Le Cénomanien du Katran Dağ (= Sam Dag) près d'Antalya (Turquie). Bulletin of the Mining Research and Exploration Institute of Turkey, 82, 71-77.

Calonge, A. 1989. Bioestratigrafía del Cenomaniense de la Cordillera Ibérica por foraminíferos bentónicos. $\mathrm{PhD}$ Thesis, Universidad Complutense de Madrid (unpublished).

Calonge, A. 1996. Soritids of Cretaceous from Iberian Range (Spain). Coloquios de Paleontología, 48, 25-45.

Calonge, A., Caus, E., Bernaus, J.M. \& Aguilar, M. 2002. Praealveolina (foraminifera): a tool to date Cenomanian platform sediments. Micropaleontology, 48, 53-66; doi: 10.1661/0026-2803(2002)048[0053:PFSATT]2.0.CO;2.

Capote, R., Muñoz, J.A. \& Simón, J.L. 2002. Alpine tectonics I: the Alpine system north of the Betic Cordillera. In: The Geology of Spain (eds Gibbons, W. \& Moreno, T.). The Geological Society, London, 367-416.
Caus, E., Calonge, A., Bernaus, J.M. \& Chivelet, J. 2009. Mid-Cenomanian separation of Atlantic and Tethyan domains in Iberia by a land-bridge: the origin of larger foraminifera provinces? Palaeogeography, Palaeoclimatology, Palaeoecology, 283, 172-181; doi: 10.1016/j.palaeo.2009.09.019.

Cherchi, A. \& Schroeder, R. 1985. Vidalina radoicicae $\mathrm{n}$. sp. and Pseudorhapydionina (?) anglonensis (Foram.) from the Upper Cenomanian of Anglona region (NW Sardinia). Bollettino della Società Paleontologica Italiana, 24, 185-188.

Chiocchini, M., Pampaloni, M.L. \& Pichezzi R.M. (eds) 2012. Microfacies and Microfossils of the Mesozoic Carbonate Successions of Latium and Abruzzi (Central Italy). Memorie per Servire alla Descrizione della Carta Geologica d'Italia, ISPRA, Dipartimento Difesa del Suolo, Roma.

Consorti, L., Caus, E., Frijia, G. \& Yazdi-Moghadam, M., 2015. Praetaberina new genus (type species: Taberina bingistani Henson, 1948): a stratigraphic marker for the Late Cenomanian. The Journal of Foraminiferal Research, 45, 370-389; doi: 10.2113/gsjfr.45.4.378.

Consorti, L., Boix, C. \& Caus, E. 2016. Pseudorhapydionina bilottei sp. nov., an endemic foraminifera from the postCenomanian/Turonian boundary (Pyrenees, NE Spain). Cretaceous Research, 59, 147-154; doi: 10.1016/j. cretres.2015.10.021.

Crescenti, U. 1964. Praerhapydionina murgiana n. sp. (foraminifero) e Neomacroporella cretacica n. gen. n. sp. (Alga calcarea-Dasicladacea), nuovi microfossili del Cretacico dell'Italia Meridionale. Bollettino della Società Geologica Italiana, 85, 3-13.

De Castro, P. 1965. Su alcune Soritidae (Foraminiferida) del Cretacico della Campania. Note stratigrafiche sul gruppo montuoso del Tifata. Bollettino Societa dei Naturalisti in Napoli, 74, 317-372.

De Castro, P. 1972. Osservazioni sui generi Rhapydionina Stache e Rhipidionina Stache (Foraminiferida). Atti Accademia Pontiniana, 21, 1-42.

De Castro, P. 1983. Cisalveolina fraasi (Gümbel) Reichel, Foraminiferida: diffusione geografica e problemi stratigrafici. Bollettino Società dei Naturalisti in Napoli, 90, 99-130.

De Castro, P. 1985. Pseudorhapydionina dubia (De Castro, 1965). Pseudorhapydionina laurinensis (De Castro, 1965). Pseudorhipidionina casertana (De Castro, 1965). In: Les grands Foraminifères du Crétacé moyen de la région méditerranéenne (eds Schroeder, R. \& Neumann, M.). Geobios, Mémoire Spécial, 7, 86-97, 102-109, 123-138.

De Castro, P. 2006. Praerhapydionina murgiana Crescenti, 1964: emendation and transfer to the genus Pseudorhipidionina De Castro, 1972 (Foraminiferida, Upper Cenomanian, Italy). Bollettino della Società Paleontologica Italiana, 45, 43-59.

Delage, Y. \& Hérouard, E. 1896. Traité de Zoologie Concrète. La Cellule et les Protozoaires, 1. Schleicher frères, Paris.

d'Orbigny, A. 1826. Tableau methodique de la classe des Céphalopodes. Annales des Sciences Naturelles, 7, 245-314. 
Dercourt, J., Gaetani, M., Vryelinck, B., Barrier, E., Biju-Duval, B., Brunet, M.F., Cadet, J.P., Crasquin, S. \& Sandulescu, M. (eds) 2000. Atlas Peri-Tethys, Paleogeographical Maps. CCGM/CGMW. Paris.

Fleury, J.J. (ed.) 1980. Les Zones de Gavrovo-Tripolitza et du Pinde-Olonos (Grèce Continentale et Péloponnèse du Nord). Évolution d'une Plate-Forme et d'un Bassin dans leur Cadre Alpin. Publications de la Société Géologique du Nord 4, Villeneuve d'Ascq.

Frijia, G., Parente, M., Di Lucia, M. \& Mutti, M. 2015. Carbon and strontium isotope stratigraphy of the Upper Cretaceous (Cenomanian-Campanian) shallow-water carbonates of southern Italy: Chronostratigraphic calibration of larger foraminifera biostratigraphy. Cretaceous Research, 53, 110-139; doi: 10.1016/j.cretres.2014.11.002.

Giménez, R. 1987. Estratigrafía y sedimentología del Cretácico Superior en el sector Almansa-Requena (provincias de Albacete y Valencia). PhD Thesis, Universidad Complutense de Madrid (unpublished).

Hamaoui, M. \& Foucade, E. 1973. Révision des Rhapydionininae (Alveolinidae, foraminifères). Bulletin du Centre de Recherches de Pau, 7, 361-393.

Martín-Chivelet, J. \& Giménez, R. 1993. Évolutions sédimentaires et tectoniques des plates-formes du sudest de l'Espagne au cours du Cénomanien superieurConiacien inferieur. Cretaceous Research, 14, 509-518; doi: 10.1006/cres.1993.1036.

Parente, M., Frijia, G., Di Lucia, M., Jenkyns, H.C., Woodfine, R.G. \& Baroncini, F. 2008. Stepwise extinction of larger foraminifera at the Cenomanian- Turonian boudary: a shallow-water perspective on nutrient fluctuation during Oceanic Anoxic Event 2 (Bonarelli Event). Geology, 36, 715-718; doi: 10.1130/G24893A.

Pawlowski, J., Holzmann, M. \& Tyszka, J. 2013. New supraordinal classification of Foraminifera: Molecules meet morphology. Marine Micropaleontology, 100, 1-10; doi: 10.1016/j.marmicro.2013.04.002.

Reichel, M., 1936-37. Etude sur les Alvéolines. Mémoire Societé paleontologique Suisse, 57 and 59.
Robles, S. 1982. Catalánides. In: El Cretácico de España. Universidad Complutense, Madrid, 199-272.

Saint-Marc, P. (ed.) 1974. Étude Stratigraphique et Micropaléontologique de l'Albien, du Cénomanien et du Turonien du Liban. Notes et Mémoires sur le MoyenOrient, Muséum National d'Historie Naturelle, Paris.

Schroeder, R. \& Neumann, M. 1985. Les grands foraminifères du Crétacé moyen de la région Méditerranéenne. Geobios, Mémoire Spécial, 7.

Smith, A.B., Simmons, M.D. \& Racey, A. 1990. Cenomanian echinoids, larger foraminifera and calcareous algae from the Natih Formation, central Oman Mountains. Cretaceous Research, 11, 29-69; doi: 10.1016/S0195-6671(05)80041-2.

Spalluto, L. 2012. Facies evolution and sequence chronostratigraphy of a «mid»-Cretaceous shallow-water carbonate succession of the Apulia carbonate platform from the northern Murge area (Apulia, southern Italy). Facies, 58, 17-36.

Velić, I. 2007. Stratigraphy and palaeobiogeography of Mesozoic benthic foraminifera of the Karst Dinarides (SE Europe). Geologica Croatica, 60, 1-113.

Vicedo, V., Calonge, A. \& Caus, E. 2011. Cenomanian rhapydioninids (Foraminiferida): architecture of the shell and stratigraphy. The Journal of Foraminiferal Research, 41, 41-52; doi: 10.2113/gsjfr.41.1.41.

Vilas, L., Mas, J.R., García, A., Arias, C., Alonso, A., Meléndez, N. \& Rincón, R. 1982. Ibérica suroccidental. In: El Cretácico de España. (ed. García, A.). Universidad Complutense, Madrid, 457-514.

Whittaker, J., Jones, B.W. \& Banner, F. (eds) 1998. Key Mesozoic Benthic Foraminifera of the Middle East. The Natural History Museum, London.

Zarcone, G., Petti, F.M., Cillari, A., Di Stefano, P., Guzzetta, D. \& Nicosia, U. 2010. A possible bridge between Adria and Africa: New palaeobiogeographic and stratigraphic constrains on the Mesozoic palaeogeography of the Central Mediterranean area. Earth-Science Reviews, 103, 154-162; doi: 10.1016/j.earscirev.2010.09.005. 